\title{
Labyrinthe
}

14 | 2003

Constructions de la raison

\section{Le système néovitaliste de Hans Driesch}

\section{Charles Ruelle}

\section{(2) OpenEdition}

Journals

Édition électronique

URL : http://journals.openedition.org/labyrinthe/597

DOI : $10.4000 /$ labyrinthe.597

ISSN : 1950-6031

Éditeur

Hermann

Édition imprimée

Date de publication : 1 mai 2003

Pagination : 47-55

Référence électronique

Charles Ruelle, "Le système néovitaliste de Hans Driesch », Labyrinthe [En ligne], 14 | 2003, mis en ligne le 11 avril 2005, consulté le 01 mai 2019. URL : http://journals.openedition.org/labyrinthe/597 ; DOI : 10.4000/labyrinthe.597

Ce document a été généré automatiquement le 1 mai 2019.

Propriété intellectuelle 


\section{Le système néovitaliste de Hans Driesch}

Charles Ruelle 